\title{
ASTHMA
}

\section{Cough receptor sensitivity to capsaicin does not change after allergen bronchoprovocation in allergic asthma}

\author{
H Minoguchi, K Minoguchi, A Tanaka, H Matsuo, N Kihara, M Adachi
}

Thorax 2003;58: 19-22

See end of article for authors' affiliations

Correspondence to:

Dr K Minoguchi, First Department of Internal Medicine, Showa

University, School of Medicine, 1-5-8

Hatanodai, Shinagawa-ku,

Tokyo 142, Japan;

minochan@fn.catv.ne.jp

Revised version received

12 August 2002

Accepted for publication

12 August 2002 lic inflammation of the Background: The relationship between cough r
airway in patients with asthma remains unclear.

Methods: Eighteen patients with asthma sensitised to house dust mite (HDM) were enrolled in a randomised parallel group study. Patients with asthma whose main symptom was cough were not enrolled in the study. Half the patients were randomly assigned to inhale saline and the other half to inhale HDM allergen. Cough receptor sensitivity to capsaicin, airway responsiveness to histamine, and sputum eosinophils analysed with hypertonic saline inhalation were investigated before and 24 hours after saline or HDM allergen bronchoprovocation.

Results: Patients inhaling saline showed no significant changes in sputum eosinophils (from $7.87 \%$ (95\% confidence interval (Cl) 5.08 to 12.19$)$ to $8.60 \%(95 \% \mathrm{Cl} 3.03$ to 14.18$) ; p=0.97)$, airway responsiveness to histamine (from $726.68 \mathrm{\mu g} / \mathrm{ml}(95 \% \mathrm{Cl} 251.90$ to 2096.36 ) to $773.01 \mathrm{\mu g} / \mathrm{ml}$ $(95 \% \mathrm{Cl} 251.36$ to 2377.23$) ; p=0.96)$, or capsaicin sensitivity (from $7.23 \mu \mathrm{M}(95 \% \mathrm{Cl} 2.45$ to $21.31)$ to $7.24 \mu \mathrm{M}(95 \% \mathrm{Cl} 2.46$ to 21.31$) ; p=0.96)$. Early asthmatic response was induced in all patients, and late asthmatic response was observed in six of nine patients inhaling HDM allergen. Although there were significant increases in sputum eosinophils (from 9.83\% (95\% Cl 6.78 to 14.27) to $21.00 \%(95 \% \mathrm{Cl} 13.85$ to 28.15$) ; \mathrm{p}<0.01)$ and airway responsiveness to histamine (from $784.16 \mu \mathrm{g} / \mathrm{ml}(95 \% \mathrm{Cl} 318.24$ to 1932.24$)$ to $377.81 \mu \mathrm{g} / \mathrm{ml}(95 \% \mathrm{Cl} 118.43$ to 1205.24); $\mathrm{p}<0.05) 24$ hours after HDM allergen inhalation compared with baseline levels, capsaicin sensitivity did not change significantly (from $5.75 \mu \mathrm{M}(95 \% \mathrm{Cl} 1.91$ to 17.30$)$ to $6.20 \mu \mathrm{M}(95 \% \mathrm{Cl} 2.21$ to 17.38); $p=0.77)$.

Conclusions: These findings suggest that cough receptor sensitivity to capsaicin is not associated with eosinophilic inflammation of the airway in patients with allergic asthma whose main symptoms are wheezing and dyspnoea but not cough.
C ough is an important symptom in patients with asthma, eosinophilic bronchitis, or airway infections. ${ }^{1-4}$ Cough receptor sensitivity to inhaled capsaicin, the pungent extract of red pepper, is increased in these conditions but returns to the normal range after cough becomes less severe. ${ }^{5}{ }^{6}$ Cough receptor sensitivity to capsaicin might therefore be a useful marker for disease severity for coughing.

Recent findings suggest that cough receptor sensitivity is related to airway inflammation in asthma. In a subgroup of children, cough receptor sensitivity was increased in severe exacerbation of asthma and decreased after treatment. ${ }^{7}$ In addition, treatment with inhaled corticosteroids slightly but significantly decreased cough receptor sensitivity to citric acid in patients with asthma. ${ }^{8}$ However, cough receptor sensitivity does not differ significantly between patients with asthma and healthy subjects, ${ }^{910}$ and is not related to the airway hyperresponsiveness that is closely associated with airway inflammation in patients with asthma. ${ }^{11}$

The purpose of this study was to evaluate the effect on cough receptor sensitivity to capsaicin of allergen bronchoprovocation, which leads to increases in airway eosinophils and airway responsiveness in patients with asthma sensitised to house dust mite (HDM).

\section{METHODS}

\section{Subjects}

The subject group comprised 18 non-smoking patients with mild asthma who were sensitised to HDM. All subjects were allergic as defined by high levels of IgE specific for house dust and Dermatophagoides farinae (Der f) in serum samples. At the time of referral the subjects had had no respiratory infections in the previous 6 weeks. Asthma in all subjects was controlled with inhaled $\beta_{2}$ agonists as required, and inhaled or oral steroids had not been used in the previous 12 weeks. The baseline forced expiratory volume in 1 second $\left(\mathrm{FEV}_{1}\right)$ was more than $70 \%$ of the predicted values and improved more than $15 \%$ with inhalation of a $\beta_{2}$ agonist. Patients with asthma whose main symptom was cough were not enrolled in the study. The total symptom scores per week were estimated according to the rating standards established by the Japanese Society of Allergology as follows: breathlessness and wheezing on a scale of 0-9 (0: no symptoms; l: breathlessness or wheezing; 3 : mild asthma attack; 6: moderate asthma attack; 9: severe asthma attack); and cough on a scale of 0.5-1 (0.5: infrequent cough; l: frequent cough).

\section{Study design}

This was a randomised parallel group study. All patients underwent haematological studies and tests to assess cough receptor sensitivity to capsaicin, airway responsiveness to histamine, and sputum induction with hypertonic saline inhalation. Twenty four hours after these examinations the patients were randomly divided into two groups and challenged with either inhaled saline or HDM allergen. Examinations of cough receptor sensitivity to capsaicin, airway responsiveness to histamine, and analysis of sputum eosinophils were performed again 24 hours after the challenge. All medications were withheld from at least 12 hours before the start of the study to the end of the study period. The examinations were performed at approximately the same time each day with the same equipment by the same technicians. The study was approved 
Table 1 Mean data with $95 \%$ confidence intervals (Cl) of study subjects

\begin{tabular}{|c|c|c|c|c|c|}
\hline \multirow[b]{2}{*}{ Parameter } & \multicolumn{2}{|c|}{ Saline group } & \multicolumn{2}{|c|}{ HDM group } & \multirow[b]{2}{*}{$p$ value } \\
\hline & Mean & $95 \% \mathrm{Cl}$ & Mean & $95 \% \mathrm{Cl}$ & \\
\hline $\operatorname{Sex}(M / F)$ & \multicolumn{2}{|r|}{$4 / 5$} & \multicolumn{2}{|r|}{$5 / 4$} & \\
\hline Age (year) & 27.1 & 21.2 to 33.0 & 27.3 & 22.1 to 32.6 & 0.95 \\
\hline Symptom score (/week) & 0.47 & 0.06 to 0.89 & 0.59 & 0.16 to 1.02 & 0.68 \\
\hline$\beta_{2}$ agonist use (puff/week) & 0.29 & 0.06 to 0.62 & 0.22 & 0.05 to 0.50 & 0.87 \\
\hline Der f lgE (UA/ml) & 34.3 & 20.2 to 58.2 & 40.3 & 20.1 to 81.1 & 0.68 \\
\hline $\mathrm{FEV}_{1}$ (I) & 2.95 & 2.69 to 3.22 & 2.99 & 2.71 to 3.27 & 0.65 \\
\hline $\mathrm{FEV}_{1}, \%$ predicted (\%) & 95.1 & 91.7 to 98.5 & 94.4 & 91.0 to 97.9 & 0.79 \\
\hline Capsaicin $(C 5, \mu M)$ & 7.23 & 2.45 to 21.3 & 5.75 & 1.91 to 17.3 & 0.74 \\
\hline Histamine $\mathrm{PC}_{20}(\mu \mathrm{g} / \mathrm{ml})$ & 727 & 252 to 2096 & 784 & 318 to 1932 & 0.90 \\
\hline Sp-eos $(\%)$ & 7.87 & 5.08 to 12.19 & 9.83 & 6.78 to 14.27 & 0.36 \\
\hline $\begin{array}{l}\mathrm{FEV} \mathrm{V}_{1}=\text { forced expiratory volu } \\
\text { histamine } \mathrm{PC}_{20}=\text { provocative } \\
\text { eosinophils. } \\
\mathrm{p} \text { value for comparison bet }\end{array}$ & $\begin{array}{l}1 \text { seco } \\
\text { atratio } \\
\text { atients }\end{array}$ & $\begin{array}{l}5=\text { capsaicin } \\
\text { histamine caus } \\
\text { line and HDN }\end{array}$ & $\begin{array}{l}\text { ntratic } \\
20 \% \\
\text { lation }\end{array}$ & $\begin{array}{l}\text { quired to cause } \\
\text { ase in } \mathrm{FEV}_{1} ; \mathrm{Sp} \\
\text { ps. }\end{array}$ & $\begin{array}{l}\text { oughs; } \\
\text { sputum }\end{array}$ \\
\hline
\end{tabular}

by the ethics committees of Kihara Hospital and Showa University, and all patients gave written informed consent.

\section{Inhalation challenge tests}

Cough receptor sensitivity to capsaicin was examined using the method described by Fujimura et al. ${ }^{12}$ Capsaicin (30.5 mg) was dissolved in Tween $80(1 \mathrm{ml})$ and ethanol $(1 \mathrm{ml})$ and then dissolved in physiological saline $(8 \mathrm{ml})$ to make a stock solution of $1 \times 10^{-2} \mathrm{M}$ which was stored at $-20^{\circ} \mathrm{C}$. This solution was diluted with physiological saline to make capsaicin solutions of $0.49,0.98,1.95,3.9,7.8,15.6,31.2,62.5,125,250,500$, and $1000 \mu \mathrm{M}$. After the subjects had inhaled normal saline, they inhaled doubling concentrations of capsaicin for 15 seconds by tidal mouth breathing while wearing a noseclip every 1 minute with a nebuliser (DeVilbiss, Somerset, PA, USA) operated by compressed air at $5 \mathrm{l} / \mathrm{min}$ until five or more coughs (C5) were elicited. The nebuliser output was $0.21 \mathrm{ml} / \mathrm{min}$.

After capsaicin inhalation challenge, bronchial responsiveness to histamine was also measured using a method described previously. ${ }^{13}$ Subjects inhaled doubling concentrations of histamine for 2 minutes by tidal breathing until FEV decreased by more than $20 \%$ of the baseline value. The results are expressed as the concentration provoking a $20 \%$ fall in $\mathrm{FEV}_{1}\left(\mathrm{PC}_{20}\right)$. The measured values were plotted on semilogarithmic graph paper and the $\mathrm{PC}_{20}$ values were calculated.

Sputum induction and analysis of the percentage of eosinophils were performed before and 24 hours after allergen inhalation challenge as described previously. ${ }^{14}$ Briefly, sputum was induced by inhalation of increasing concentrations of hypertonic saline $(0.9 \%, 1.8 \%, 3 \%, 4 \%$, and $5 \%)$ with a nebuliser (DeVilbiss) until approximately $400 \mu \mathrm{l}$ of sputum had been collected. FEV ${ }_{1}$ was measured before and every 5 minutes during inhalation of hypertonic saline solution. Sputum induction was ceased when an adequate sample had been obtained, if $\mathrm{FEV}_{1}$ became less than $20 \%$ of the preinduction baseline, or at the patients's request. Patients were encouraged to cough deeply after each inhalation. Cell plugs in sputum were separated from saliva and collected. Sputum cells were then spread on slides and treated with Wright-Giemsa stain so that the inflammatory cells could be counted. We have previously reported the reproducibility of the percentage of eosinophils in sputum with this method..$^{13}{ }^{14}$ The percentages of total eosinophils was determined by counting 900 inflammatory cells under a light microscope. All slides were counted independently by two readers blinded to the type of inhalation. The percentages of sputum eosinophils are expressed as mean values. The sputum induction test was performed after the histamine test.

For the allergen inhalation challenge test, baseline spirometric tests were performed, after which patients inhaled $0.9 \%$ saline followed by dilutions of HDM extract starting with the lowest concentration, using a DeVilbiss nebuliser by a method described previously. ${ }^{13}$ If $\mathrm{FEV}_{1}$ had not fallen by at least $20 \%$ from the postsaline value, allergen inhalation was continued until a fall in $\mathrm{FEV}_{1}$ of at least $20 \%$ occurred. The FEV , was monitored until 24 hours after allergen challenge. For saline challenge, patients inhaled $0.9 \%$ saline for 2 minutes, after which $\mathrm{FEV}_{1}$ was measured at 5, 10, and 15 minutes after allergen challenge to identify an early asthmatic response (EAR) and hourly for 8 hours to detect a late asthmatic response (LAR), and at 24 hours after allergen challenge.

\section{Statistical analysis}

Data are expressed as means (95\% confidence intervals (CI)) unless otherwise indicated. The significance of changes within groups was assessed using the Student's paired $t$ test, and changes between groups were assessed using the MannWhitney U test. Correlation was assessed with Pearson's correlation coefficient. Differences with a probability of less than 0.05 were considered significant.

\section{RESULTS}

All subjects completed the trial. The baseline characteristics of the patients are presented in table 1. Patients inhaling saline and those inhaling HDM showed no significant differences in age, symptom score, $\beta_{2}$ agonist use, titre of Der $f$ specific IgE, $\mathrm{FEV}_{1}, \mathrm{FEV}_{1} \%$ predicted, cough receptor sensitivity to capsaicin, airway responsiveness to histamine, or sputum eosinophils. Sputum was successfully induced and collected both before and 24 hours after allergen challenge in seven of nine patients inhaling saline and in eight of nine patients inhaling HDM allergen.

\section{Change in $\mathrm{FEV}_{1}$ after allergen inhalation}

In patients inhaling saline, no significant changes in $\mathrm{FEV}_{1}$ were observed until 24 hours after saline inhalation. The percentage change in $\mathrm{FEV}_{1}$ was $0.67 \%$ (95\% CI -0.87 to 2.20 ) at the early phase and $0.12 \%(95 \%$ CI -1.80 to 2.04$)$ at the late phase (fig 1). Bronchoprovocation with HDM allergen induced an EAR in all patients and a LAR in six of nine patients (fig l). The percentage decrease in $\mathrm{FEV}_{1}$ was $-28.93 \%$ (95\% CI -25.61 to -32.26$)$ at EAR and $-22.44 \%(95 \% \mathrm{CI}-12.13$ to -32.76$)$ at LAR. The FEV before (2.99 l (95\% CI 2.71 to 3.27)) and 24 hours after (2.90 l (95\% CI 2.61 to 3.19)) HDM allergen challenge did not differ significantly $(\mathrm{p}=0.16)$.

\section{Changes in cough receptor sensitivity to capsaicin}

The effect of HDM allergen inhalation challenge on capsaicin sensitivity was investigated. Saline inhalation did not significantly change capsaicin sensitivity $(7.23 \mu \mathrm{M}$ (95\% CI 2.45 to 21.31 ) before inhalation, $7.24 \mu \mathrm{M}$ (95\% CI 2.46 to 21.31 ) 24 


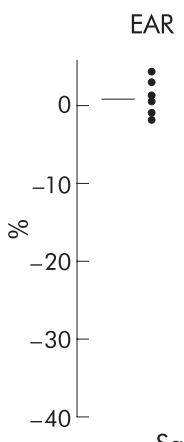

Saline group
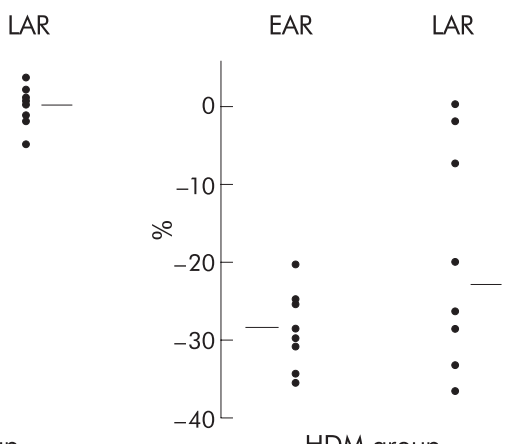

Figure 1 Percentage change in $\mathrm{FEV}_{1}$ after bronchoprovocation with saline or HDM allergen in patients with allergic asthma. Individual values and geometric means are shown. EAR=early asthmatic response, $L A R=$ late asthmatic response.

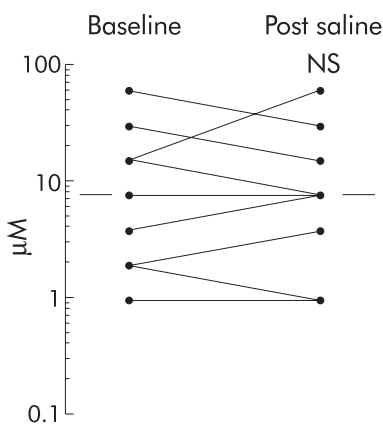

Saline group

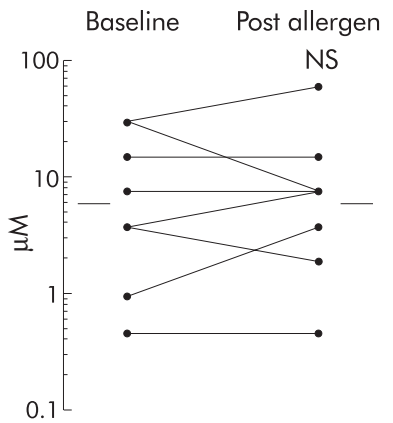

HDM group
Figure 2 Changes in cough receptor sensitivity to inhaled capsaicin after bronchoprovocation with saline or HDM allergen in patients with allergic asthma. Individual values and geometric means are shown. NS=not significant.

hours after inhalation), a finding that suggests capsaicin sensitivity measured at 48 hour intervals is reproducible and that tachyphylaxis to capsaicin is not induced in patients with asthma ( $p=0.96$, fig 2 ). In addition, bronchoprovocation with allergen did not significantly change cough receptor sensitivity to capsaicin in patients with allergic asthma $(5.75 \mu \mathrm{M}$ (95\% CI 1.91 to 17.30 ) before bronchoprovocation, $6.20 \mu \mathrm{M}$ (95\% CI 2.21 to 17.38 ) after bronchoprovocation; $p=0.77$, fig 2).

\section{Changes in airway responsiveness to histamine and sputum eosinophils}

Changes in airway responsiveness to histamine and sputum eosinophils were investigated before and 24 hours after saline or HDM allergen challenge (figs 3 and 4). Saline inhalation did not significantly change either airway responsiveness to histamine $(726.68 \mu \mathrm{g} / \mathrm{ml}$ (95\% CI 251.90 to 2096.36) before inhalation, $773.01 \mu \mathrm{g} / \mathrm{ml}$ (95\% CI 251.36 to 2377.23 ) after inhalation; $\mathrm{p}=0.96)$ or sputum eosinophils $(7.87 \%(95 \% \mathrm{CI}$ 5.08 to 12.19 ) before inhalation, $8.60 \%$ (95\% CI 3.03 to 14.18 ) after inhalation; $p=0.97$ ). In patients inhaling HDM allergen, bronchoprovocation significantly increased airway responsiveness to histamine (from $784.16 \mu \mathrm{g} / \mathrm{ml}(95 \%$ CI 318.24 to 1932.24 ) to $377.81 \mu \mathrm{g} / \mathrm{ml}$ (95\% CI 118.43 to 1205.24$) ; \mathrm{p}<0.05$ ) and sputum eosinophils (from $9.83 \%$ (95\% CI 6.78 to 14.27 ) to $21.00 \%$ (95\% CI 13.85 to 28.15 ); $p<0.01$ ) 24 hours after challenge compared with baseline values. The coefficient of variability of sputum eosinophils between two independent observers was $r=0.8633$ before challenge and $r=0.927$ after saline or allergen challenge. There was no significant correlation between the changes in sputum eosinophils and capsaicin

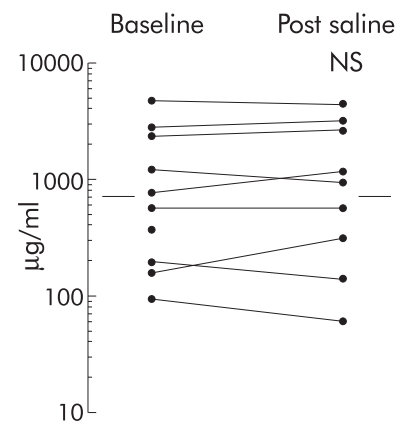

Saline group

Figure 3 Changes in airway responsiveness to histamine after bronchoprovocation with saline or HDM allergen in patients with allergic asthma. Individual values and geometric means are shown. $\mathrm{NS}=$ not significant. ${ }^{*} \mathrm{p}<0.05$.
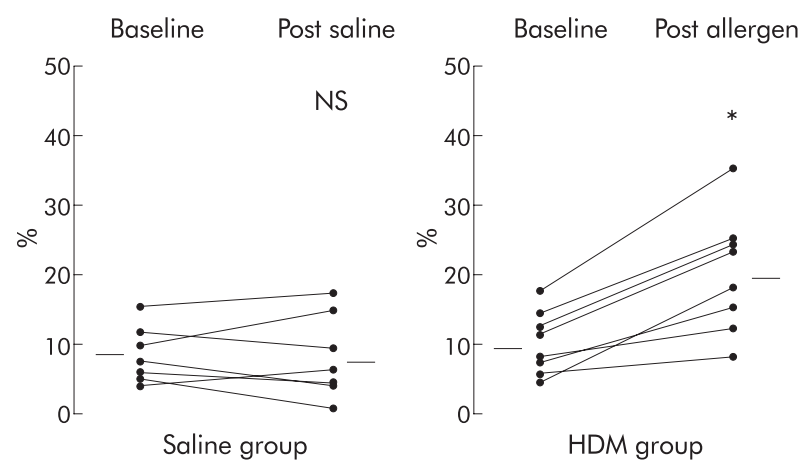

Figure 4 Changes in sputum eosinophils after bronchoprovocation with saline or HDM allergen in patients with allergic asthma. Individual values and geometric means are shown. NS=not significant. ${ }^{*} p<0.01$.

cough reflex sensitivity following allergen challenge in patients with asthma $(r=0.11 ; \mathrm{p}=0.80)$.

\section{DISCUSSION}

We have investigated the effects on cough receptor sensitivity to capsaicin of allergen bronchoprovocation that exacerbated eosinophilic inflammation of the airway and enhanced airway responsiveness in patients with HDM sensitised asthma. Although the results of some studies suggest a relationship between airway inflammation and cough receptor sensitivity in patients with asthma, we found no significant changes in cough receptor sensitivity to capsaicin after allergen challenge despite increases in both sputum eosinophils and airway responsiveness to histamine. We therefore conclude that cough receptor sensitivity to capsaicin is not regulated mainly by either eosinophilic inflammation or airway hyperresponsiveness in patients with allergic asthma whose main symptoms are wheezing and dyspnoea but not cough.

Capsaicin stimulates unmyelinated slow $\mathrm{C}$ fibres of the sensory nervous system and has been used to induce cough in models of provocation challenge in a wide range of diseases. ${ }^{15} 16$ Cough receptor sensitivity in children with asthma who have troublesome cough is enhanced during the acute severe phase but decreases thereafter to levels similar to those in children with asthma without cough. ${ }^{7}$ In addition, a recent study has shown that treatment with inhaled steroids increases the cough threshold to inhaled citric acid in patients with asthma. ${ }^{8}$ Similarly, treatment with inhaled steroids decreases sputum eosinophils and capsaicin sensitivity in patients with eosinophilic bronchitis, another cause of chronic cough. ${ }^{17}$ These results therefore suggest a close relationship 
between cough receptor sensitivity and eosinophilic inflammation of the airway. However, direct studies investigating the relationship between cough receptor sensitivity and eosinophilic airway inflammation have not been fully studied in asthma. Some studies have found no difference in cough receptor sensitivity between healthy subjects and patients with asthma. ${ }^{9}$ We found no significant changes in capsaicin sensitivity despite an increase in sputum eosinophils after allergen bronchoprovocation in patients with allergic asthma. Airway inflammation might not therefore be a critical factor for regulating airway cough receptor sensitivity to capsaicin in allergic asthma.

The severity of cough in asthma might be related to airway calibre because cough can be related to the degree of airflow obstruction that stimulates irritant receptors. ${ }^{18}$ Although the pathogenesis of chronic obstructive pulmonary disease (COPD) is different from that of asthma, no relationship has been found between capsaicin sensitivity and airflow limitation, as reflected by $\mathrm{FEV}_{1}$, in patients with COPD. ${ }^{19}$ In the present study the values of $\mathrm{FEV}_{1}$ before and 24 hours after allergen inhalation did not differ significantly in patients who inhaled HDM allergen. We therefore found no evidence that airway calibre affects capsaicin sensitivity.

Airway hyperresponsiveness is an important feature of asthma that is also closely associated with airway inflammation..$^{20}$ Bronchoprovocation with allergen exacerbates airway inflammation that enhances airway responsiveness..$^{13}$ In the present study airway responsiveness to histamine increased significantly 24 hours after allergen challenge, but capsaicin sensitivity did not change significantly. Moreover, cough receptor sensitivity to capsaicin is not related to the level of airway hyperresponsiveness in patients with asthma. ${ }^{11}$ Previous findings and our present results therefore confirm that cough receptor sensitivity to inhaled capsaicin does not correlate with airway hyperresponsiveness in patients with asthma.

Several techniques have been developed to investigate airway inflammation in asthma; analysis of induced sputum is particularly useful because it is repeatable and can be used to monitor changes in airway inflammation. ${ }^{21}$ In the present study sputum was induced immediately after capsaicin and histamine challenge. Bronchial provocation with histamine increases lymphocyte, mast cell, and neutrophil counts, but not the eosinophil count, in bronchoalveolar lavage fluid. ${ }^{22}$ Capsaicin nasal challenge significantly increases the number of eosinophils in nasal lavage fluid. ${ }^{23}$ Therefore, capsaicin bronchoprovocation might also increase the number of eosinophils in sputum both at baseline and after saline or allergen challenge. Although the effects of both capsaicin and histamine challenge on sputum eosinophils have not been completely elucidated, our data from patients inhaling saline suggest that such challenges do not cause significant differences in the number of sputum eosinophils before and 24 hours after inhalation.

Our results clearly show that bronchoprovocation with allergen does not increase cough receptor sensitivity to capsaicin in patients with allergic asthma. We therefore conclude that cough receptor sensitivity to inhaled capsaicin is not related to eosinophilic inflammation of the airway or airway hyperresponsiveness in patients with allergic asthma whose main symptoms are wheezing and dyspnoea but not cough.

\section{ACKNOWLEDGEMENT}

The authors wish to thank Dr Yasurou Kohno and Miss Tomoko Akabane for their skillful technical assistance.

\section{Authors' affiliations}

H Minoguchi, K Minoguchi, A Tanaka, H Matsuo, M Adachi, First

Department of Internal Medicine, Showa University, Tokyo, Japan

H Minoguchi, N Kihara, Department of Respirology, Kihara Hospital,

Tokyo, Japan

\section{REFERENCES}

1 Irwin RS, Corrao WM, Pratter MR. Chronic persistent cough in the adult: the spectrum and frequency of causes and successful outcome of specific therapy. Am Rev Respir Dis 1981;123:413-7.

2 Corrao WN, Braman SS, Irwin RS. Chronic cough as the sole presenting manifestation of bronchial asthma. N Engl J Med 1979;300:633-7.

3 Gibson PG, Dolovich J, Denburg J, et al. Chronic cough: eosinophilic bronchitis without asthma. Lancet 1989;i:1346-8.

4 Brightling CE, Ward R, Goh KL, et al. Eosinophilic bronchitis is an important cause of chronic cough. Am J Respir Crit Care Med 1999:160:406-10.

5 O'Connell F, Thomas VE, Pride NB, et al. Capsaicin cough sensitivity decreases with successful treatment of chronic cough. Am J Respir Crit Care Med 1994;150:374-80

6 Chang AB, Phelan PD, Sawyer SM, et al. Airway hyperresponsiveness and cough-receptor sensitivity in children with recurrent cough. Am J Respir Crit Care Med 1997;155: 1935-9.

7 Chang AB, Phelan PD, Robertson CF. Cough receptor sensitivity in children with acute and non-acute asthma. Thorax 1997:52:770-4.

8 Di Franco A, Dente FL, Giannini D, et al. Effects of inhaled corticosteroids on cough threshold in patients with bronchial asthma. Pulm Pharmacol Ther 2001;14:35-40.

9 Fujimura $M$, Sakamoto S, Kamio Y, et al. Cough receptor sensitivity and bronchial responsiveness in normal and asthmatic subjects. Eur Respir J 1992:5:291-5.

10 Shimizu T, Mochizuki H, Tokuyama K, et al. Relationship between the acid-induced cough response and airway responsiveness and obstruction in children with asthma. Thorax 1996;51:284-7.

11 Fujimura $M$, Kamio Y, Hashimoto T, et al. Airway cough sensitivity to inhaled capsaicin and bronchial responsiveness to methacholine in asthmatic and bronchitis subjects. Respirology 1998;3:267-72

12 Fujimura M, Kasahara K, Yasui M, et al. Atopy in cough sensitivity to capsaicin and bronchial responsiveness in young females. Eur Respir J 1998;11:1060-3.

13 Kohno Y, Minoguchi K, Oda N, et al. Effect of rush immunotherapy on airway inflammation and airway hyperresponsiveness after bronchoprovocation with allergen in asthma. J Allergy Clin Immunol 1998; 102:927-34.

14 Minoguchi K, Kohno Y, Oda N, et al. Effect of theophylline withdrawal on airway inflammation in asthma. Clin Exp Allergy 1998;28(Suppl 3):57-63.

15 Millqvist E. Cough provocation with capsaicin is an objective way to tes sensory hyperreactivity in patients with asthma-like symptoms. Allergy 2000:55:546-50

16 Lundberg JM, Saria A. Capsaicin-induced desensitization of airway mucosa to cigarette smoke, mechanical and chemical irritants. Nature 1983;302:251-3

17 Brightling CE, Ward R, Wardlaw $\mathrm{A}$, et al. Airway inflammation, airway responsiveness and cough before and after inhaled budesonide in patients with eosinophilic bronchitis. Eur Respir J 2000;15:682-6.

18 Fujimura $M$, Kamio Y, Hashimoto T, et al. Cough receptor sensitivity and bronchial responsiveness in patients with only chronic nonproductive cough: In view of effect of bronchodilator therapy. J Asthma 1994;31:463-72.

19 Doherty MJ, Mister R, Pearson MG, et al. Capsaicin responsiveness and cough in asthma and chronic obstructive pulmonary disease. Thorax 2000;55:643-9

20 National Asthma Education Program. Expert Panel Report 2: Guidelines for the diagnosis and management of bronchial asthma. Publication no. 97-4051. Bethesda, MD: National Institutes of Health, 1997.

21 Adachi M, Miyamoto M, Minoguchi K. Induced sputum and eosinophilic inflammation. ACl Int 1998;10:176-80

22 Soderberg $M$, Lundgren R, Bjermer L, et al. Inflammatory response in bronchoalveolar lavage fluid after inhaling histamine. Allergy 1988:43:98-102.

23 Philip G, Sanico AM, Togias A. Inflammatory cellular influx follows capsaicin nasal challenge. Am J Respir Crit Care Med 1996; 153: 1222-9. 